Gut, 1988, 29, 816-820

\title{
Effect of moderate exercise on salt and water transport in the human jejunum
}

\author{
G R BARCLAY AND L A TURNBERG \\ From the Department of Medicine, Hope Hospital (University of Manchester School of Medicine)
}

\begin{abstract}
SUMmary The effect of moderate exercise on jejunal absorption was examined in seven healthy subjects using a triple lumen perfusion technique. Moderate exercise on a bicycle ergometer significantly reduced net absorption of water from $32 \cdot 0(4 \cdot 0)$ to $16 \cdot 2(6 \cdot 1) \mathrm{ml} / 30 \mathrm{~cm} / 50 \mathrm{~min}(\mathrm{p}<0 \cdot 02)$, sodium from $2.4(0.4)$ to $0.5(0.9) \mathrm{mmol} / 30 \mathrm{~cm} / 50 \mathrm{~cm}(\mathrm{p}<0.05)$, chloride from $2.0(0.4)$ to $0.3(0.7)$ $\mathrm{mmol} / 30 \mathrm{~cm} / 50 \mathrm{~min}(\mathrm{p}<0 \cdot 05)$, and potassium from $0.20(0 \cdot 02)$ to $0.01(0 \cdot 04) \mathrm{mmol} / 30 \mathrm{~cm} / 50 \mathrm{~min}$ $(\mathbf{p}<0.01)$. After exercise, water, sodium, and chloride absorption returned towards basal values, but potassium absorption remained significantly decreased. These results suggest that moderate exercise can influence jejunal absorption of salt and water in man. They support the possibility that the autonomic nervous system has a physiological role in the control of intestinal transport, although other mechanisms may be involved.
\end{abstract}

Although there is considerable evidence in animals and man, to suggest that the autonomic nervous system may influence intestinal absorption ${ }^{1-16}$ most studies have used nerve stimulation, nerve resection, or pharmacological agents rather than physiological stimuli. Some studies have recently shown changes in absorption in response to such stimuli. Reduction of circulating volume increased human jejunal absorption $^{17}$ while sham feeding ${ }^{18}$ and psychological ${ }^{16}$ or physical stress ${ }^{19}$ reduced absorption. The response to psychological stress was probably mediated through the parasympathetic nervous system as it was blocked by atropine. ${ }^{\text {th }}{ }^{\text {We have extended these observations }}$ to study the effect of moderate exercise on intestinal transport in human volunteers.

\footnotetext{
Methods

SUBJECTS

Experiments were carried out on seven healthy volunteers (five women, two men) aged between 20 and 29 years all of whom had given their informed consent, and for which the Ethical Committee of the Salford Health Authority had given permission. The subjects were physically active but none were in regular physical training.

Address for correspondence: Professor L A Turnberg. Department of Medicine. Hope Hospital (University of Manchester School of Medicine), Eccles Old Road, Salford M6 8HD.

Received for publication 12 January 1988
}

MEASUREMENT OF JEJUNAL TRANSPORT Jejunal absorption was measured using a triple lumen perfusion technique. ${ }^{21}$ After an overnight fast subjects were intubated with a triple lumen perfusion tube which incorporated a $10 \mathrm{~cm}$ mixing segment and a $30 \mathrm{~cm}$ test segment. Each aspiration lumen had an internal diameter of $1.5 \mathrm{~mm}$. Once positioned with the infusion port distal to the duodenojejunal flexure, the jejunum was perfused at $10 \mathrm{ml} / \mathrm{min}$ using a peristaltic pump. The perfusate contained $\mathrm{Na}, 136$; $\mathrm{Cl}, 105 ; \mathrm{K}, 5 ; \mathrm{SO}_{4}, 18 \mathrm{mM}$; and polyethylene glycol $4000(5 \mathrm{~g} / \mathrm{l})$ with $0.5 \mu \mathrm{Ci} / \mathrm{l}$ of ${ }^{14} \mathrm{C}$ polyethylene glycol. Fluid entering the test segment was continuously sampled at $1.4 \mathrm{ml} / \mathrm{min}$ using a peristaltic pump, while fluid leaving the test segment was collected by free syphonage. After a 60 minute equilibration period there were three separate collection periods, each lasting 50 minutes, termed the control, exercise, and recovery periods. In all studies proximal aspirates were at least $88 \%$ of that expected $(1.4 \mathrm{ml} \times 50)$ and recovery by syphonage from the distal port was at least $50 \%$ of the fluid passing this port. Collections from the proximal port started and finished five minutes after those from the distal port in each period.

STUDY DESIGN

During the middle collection period subjects undertook moderate exercise by pedalling a bicycle ergometer at a constant $15 \mathrm{~km} /$ hour (approximately 40 
revolutions per minute). The load on the ergometer was initially 0.5 kiloponds but was varied, to adjust for differences in physical fitness between subjects, so that the pulse rate was $40-50 \%$ above the mean resting rate, providing this did not induce a marked rise in systolic blood pressure or cause physical exhaustion. During the equilibrium, control, and recovery periods subjects sat upright on a high laboratory chair with their legs dependent.

To minimise stress, the following procedures were instituted. The subjects slowly advanced the perfusion tube into place over three to four hours while resting comfortably on the $x$-ray screening couch, thereby limiting exercise and distress from the tube. Once the tube was correctly positoned the subjects transferred to an adjacent room. Entry by staff into the room was restricted and 'visitors' were prohibited so that subjects remained physically and mentally rested during the exercise free period. At no time were the subjects able to smell or see food. Subjects who were unable to tolerate the tube were excluded.

ASSESSMENT OF CARDIOVASCULAR CHANGES Throughout all the three collection periods the subjects' pulse and blood pressure were recorded ever six minutes on their right arm with a Critikon Dinamap 845 vital signs monitor.

\section{ANALYSIS OF JEJUNAL SAMPLES}

An LKB Wallac Minibeta liquid scintillation counter was used to determine ${ }^{14} \mathrm{C}$ in jejunal juice. Sodium and potassium concentrations were measured with a Corning 480 flame photometer and chloride with a Corning chloride analyser. Net movements of water and electrolytes were calculated as previously described.211

Results are expressed as the mean and standard error (SE) of the mean and data from the three collection periods were compared by Student's paired $t$ test.

\section{Results}

All subjects reported that the exercise was not difficult and did not exhaust them.

\section{CARDIOVASCULAR RESPONSE}

Exercise caused a significant increase in mean pulse rate but not in blood pressure (Table 1). The increase in pulse rate was noted at the first reading in the exercise period and compared with the equivalent time in the control period remained significantly raised throughout.

NET TRANSMUCOSAL TRANSPORT

Exercise significantly reduced jejunal absorption of
Table 1 Cardiovascular responses to moderate exercise

\begin{tabular}{lcll}
\hline & & \multicolumn{2}{l}{ Blood pressure $(\mathrm{mmHg})$} \\
\cline { 3 - 4 } & Pulselmin & Systolic & Diastolic \\
\hline Control & $67 \cdot 8(4 \cdot 2)$ & $121 \cdot 7(4 \cdot 4)$ & $77 \cdot 9(4 \cdot 1)$ \\
Exercise & $103 \cdot 1(7 \cdot 1)^{\dagger}$ & $124 \cdot 2(5 \cdot 4)$ & $78 \cdot 6(2 \cdot 0)$ \\
Recovery & $72 \cdot 1(5 \cdot 4)$ & $118 \cdot 4(3 \cdot 3)$ & $74 \cdot 0(3 \cdot 4)^{*}$ \\
\hline
\end{tabular}

${ }^{*} \mathrm{p}<0 \cdot(025 ; \dagger \mathrm{p}<0.001$ compared with cont rol period.

Mean values (SE) of blood pressure and pulse rate before (control), during, and after (recovery) exercise $(n=7)$.

Table 2 Jejunal absorption in response to moderate exercise

\begin{tabular}{|c|c|c|c|c|}
\hline & $\begin{array}{l}\text { Water } \\
\mathrm{ml} / 30 \mathrm{~cm} / \\
50 \mathrm{~min}\end{array}$ & $\begin{array}{l}\text { Sodium } \\
\mathrm{mmol} / 30 \mathrm{~cm} / \\
50 \mathrm{~min}\end{array}$ & $\begin{array}{l}\text { Chloride } \\
\mathrm{mmol} / 30 \mathrm{~cm} / \\
50 \mathrm{~min}\end{array}$ & $\begin{array}{l}\text { Potassium } \\
\mathrm{mmol} / 30 \mathrm{~cm} / \\
50 \mathrm{~min}\end{array}$ \\
\hline Control & $32 \cdot 0(4 \cdot 0)$ & $2 \cdot 4(0 \cdot 4)$ & $2 \cdot 0(0 \cdot 4)$ & $0 \cdot 20(0 \cdot 02)$ \\
\hline Exercise & $16 \cdot 2(6 \cdot 1) \ddagger$ & $0.5(0.9)^{*}$ & $0.3(0.7)^{*}$ & $0 \cdot 01(0 \cdot(04) \S$ \\
\hline Recovery & $23 \cdot 8(4 \cdot 2)$ & $1 \cdot 8(0 \cdot 4)$ & $1 \cdot 8(0 \cdot 4)$ & $0.13(0.02) \dagger$ \\
\hline
\end{tabular}

${ }^{*} \mathrm{p}<0.05 ; \nmid \mathrm{p}<0.025 ; \neq \mathrm{p}<0.02 ;$ \$ $\mathrm{p}<0.01$ compared with control period.

Mean values (SE) of net jejunal water and electrolyte absorption before (control), during, and after (recovery) exercise $(n=7)$.

water, sodium, chloride, and potassium (Table 2). During the recovery period water, $\mathrm{Na}$ and $\mathrm{Cl}$ absorption returned towards control values but potassium absorption remained significantly decreased. Individual absorption rates are shown in the Figure.
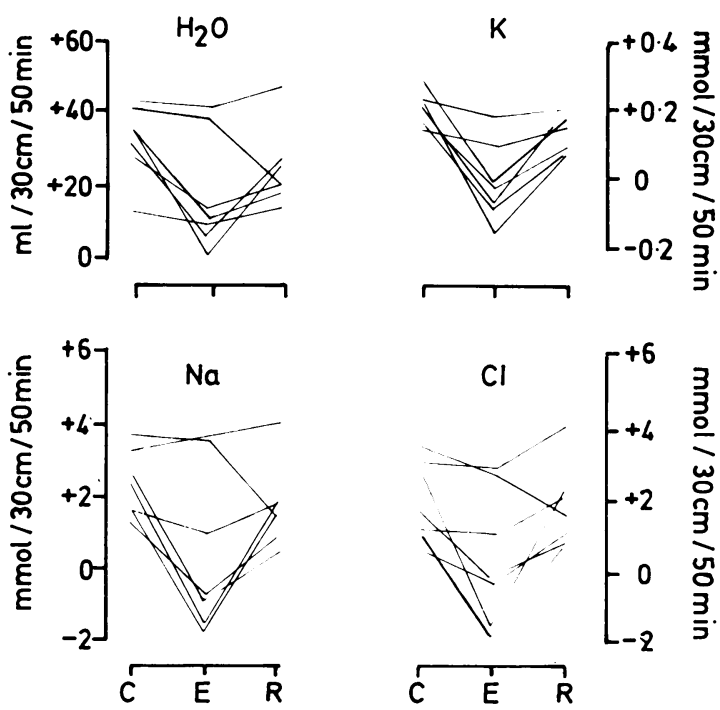

Figure Individual variations in water $\left(\mathrm{H}_{2} \mathrm{O}\right)$, potassium $(\mathrm{K})$, sodium $(\mathrm{Na})$, and chloride $(\mathrm{Cl})$ absorption in human jejunum before $(C)$, during $(E)$, and after $(R)$ exercise $(n=7)$. 


\section{Discussion}

Exercise is a known stimulant of the autonomic nervous system and much is known about its effects on cardiac, respiratory, and endocrine function..$^{21-25}$ To meet the increased metabolic needs of skeletal muscle during exercise these muscles receive an increased blood flow which is achieved by an increased cardiac output, with an associated increase in heart rate, and by a reduction in blood flow to the splanchnic vasculature. ${ }^{21-23}$ Blood pressure does not increase as much as might be expected, and may even fall, because of a reduction in total peripheral vascular resistance. ${ }^{22}$ Respiratory rate, pulmonary blood flow, ventilation, total volume, oxygen consumption and carbon dioxide production are also increased. ${ }^{212225}$ Multiple humoral mediators circulate in increased amounts during exercise including pituitary hormones, catecholamines and $\beta$ endorphin, and there is also increased activity of the renin/angiotensin/aldosterone system. ${ }^{25}$

In comparison, little is known about the effects of exercise on gastrointestinal function, although traditionally it is alleged to have a beneficial effect on constipation but an adverse effect on 'digestion'. Experimental studies have suggested that moderate and severe exercise decrease gastric secretion. ${ }^{26}$ Severe exercise inhibits gastric emptying, ${ }^{26-2 x}$ but moderate exercise accelerates gastric emptying ${ }^{2627}$ while having no effect on small intestinal transit. ${ }^{29}$ Indirect assessment of intestinal absorption, using 3-0-methyl glucose, suggested that moderate exercise reduced absorption ${ }^{31}$. whereas in the only study directly measuring small intestinal absorption severe exercise was reported to have no effect on the absorption of water, salt or glucose. ${ }^{2 x}$ It has been postulated that the different gastrointestinal responses to exercise may be due to a relative predominance of parasympathetic tone during moderate exercise compared with a relative predominance of sympathetic tone during severe exercise. ${ }^{29}$ We therefore decided to study the effect of moderate exercise, a common 'physiological' stimulus, on jejunal absorption of salt and water using a triple lumen perfusion technique.

To try to ensure a predominant parasympathetic effect on the intestine our subjects pedalled against a smaller load than that previously used for moderate exercise..$^{29}$ Furthermore, as subjects who are physically fitter have a lower resting pulse rate ${ }^{22}$ the load was varied so as to increase the pulse rate by $40-50 \%$ above the resting value rather than to increase the pulse above an absolute rate, which could result in greater variation between individual's degree of exercise. That our subjects were exercised less than those in other studies of moderate exercise is borne out by their lower mean pulse rate, achieved without a sustained rise in blood pressure..$^{254}$

This modest degree of exercise significantly reduced jejunal absorption of water, $\mathrm{Na}, \mathrm{Cl}$, and $\mathrm{K}$. These results are in contrast with those of Fordtran and Saltin who found no change in small intestinal absorption. ${ }^{2 x}$ In their study, however, using a treadmill, subjects carried out severe rather than moderate exercise. In addition, their perfusion solution contained glucose which enhances absorption $^{31} 32$ and could theoretically mask small reductions in absorption. Furthermore, the glucose concentration of the perfusate varied widely between subjects from 55 to $416 \mathrm{mM} / \mathrm{l}$ and these differences may have influenced the response.

Previous in vitro and in vivo studies, in animals and man, suggest that cholinergic agents induce small intestinal secretion ${ }^{1-6}$ while adrenergic agonists enhance absorption. ${ }^{4-15}$ Cholinergic and adrenergic binding receptors have also been shown on small intestinal epithelial cells. ${ }^{334}$ We have recently reported that stimulation of the central nervous system by psychological stress reduced absorption of salt and water from the human jejunum in vivo and that this reponse was probably mediated through the parasympathetic nervous system since it was blocked by atropine. ${ }^{16}$ Therefore the changes observed in this study are compatible with a parasympathetic effect on mucosal transport, although there are several other possible explanations.

First, during exercise, increased sympathetic adrenergic activity produces vasoconstriction of, and reduced blood flow through, the splanchnic

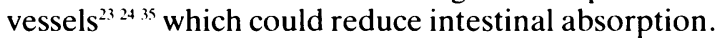
Indeed in the dog a decrease in mesenteric flow decreased glucose and xylose absorption. ${ }^{3136}$ Conversely two other studies have failed to show any alteration in absorption with changes in intestinal blood flow. ${ }^{37} 38$

Second, one or more of the humoral mediators liberated by exercise may have influenced mucosal transport. Adrenaline, noradrenaline, glucocorticoids, angiotensin, aldosterone, prolactin, and endogenous opiates, however, all of which are raised during exercise, are unlikely to have been responsible for the observed changes in jejunal transport as these enhance rather than reduce absorption. ${ }^{711139411}$ Nevertheless it is possible that exercise liberated some other neuropeptide or induced a paracrine secretion which influenced mucosal transport.

Third, changes in small intestinal motility and transit may have influenced mucosal transport. It is also feasible that changes in muscle 'tone', possibly induced by exercise, may influence the area of mucosa available for absorption. Cammock et al, however, reported that moderate exercise had no 
effect on small bowel transit time ${ }^{29}$ and previous small intestinal perfusion studies have failed to show any relationship between motility or transit time and intestinal transport."

Thus it seems likely that the reduction in absorption noted during exercise reported in this study was mediated directly or indirectly via the parasympathetic division of the autonomic nervous system, although a reduction in mucosal blood flow, possibly induced by a sympathetic visceral vasoconstriction cannot be excluded.

We are grateful to the Medical Research Council and to the North Western Regional Health Authority for grants to support this work. We are also indebed to Mr R Marcuson for loan of the bicycle ergometer, Linda Hall for her technical assistance, Julie Rostron for her patience in producing this manuscript and the Department of Medical Illustration at Hope Hospital for the Figure.

\section{References}

1 Wright RD, Jennings MA, Florey HW, Lium R. The influence of nerves and drugs on secretion by the small intestine and an investigation of the enzymes in intestinal juice. $Q J$ Exp Physiol 1940; 30: 73-120.

2 Tidball CS. Active chloride transport during intestinal secretion. Am J Physiol 1961; 200: 309-12.

3 Hardcastle PT, Eggenton J. The effect of acetylcholine on the electrical activity of intestinal epithelial cells. Biochim Biophys Acta 1973; 298: 95-100.

4 Hubel KA. Intestinal ion transport: effect of norepinephrine, pilocarpine and atropine. Am J Physiol 1976; 231: $252-7$.

5 Hubel KA. Effect of bethanecol on intestinal ion transport in the rat. Proc Soc Exp Biol Med 1977; 154: 41-4.

6 Morris AI, Turnberg LA. Influence of a parasympathetic agonist and antagonist on human intestinal transport in vivo. Gastroenterology 1980; 79: 861-6.

7 Aulsebrook KA. Intestinal absorption of glucose and sodium: effects of epinephrine and norepinephrine. Biochem Biophys Res Commun 1965; 18: 165-9.

8 Dorey PG, Munday KA, Parsons BJ, Poat JA, Upsher ME. Effect of chemical sympathectomy and ganglionic blockade on angiogensin stimulated fluid absorption in the rat jejunum. $J$ Endocrinol 1981; 91: 205-11.

9 Nakaki T, Nakadate T, Yamamoto S, Kato R. $\alpha$-2adrenoreceptors inhibit the cholera toxin induced intestinal fluid accumulation. Naunyn Schmiedebergs Arch Pharmacol 1982; 318: 181-4.

10 Nakaki T, Nakadate T, Yamamoto S, Kato R. $\alpha-2$ adrenergic inhibition of intestinal secretion induced by prostaglandin $E_{1}$, vasoactive intestinal peptide and dibutyryl cAMP in rat jejunum. $J$ Pharmacol Exp Ther 1982; 220: 637-41.

11 Field M, McColl I. Ion transport in rabbit ileal mucosa. III. Effects of catecholamines. Am J Physiol 1973; 225: $852-7$.
12 Durbin T, Rosenthal L, McArthur K, Anderson D, Dharmsathaphorn K. Clonidine and lidamidine (WHR1142) stimulated sodium and chloride absorption in the rabbit intestine. Gastroenterology 1982; 82: 1352-8.

13 Chang EB, Field M, Miller RJ. $\alpha$-2-adrenergic receptor regulation of ion transport in rabbit ileum. Am J Physiol 1982; 242: G237-42.

14 Tapper EJ, Bloom AS, Lewand DL. Endogenous norepinephrine release induced by tyramine modulates intestinal transport. Am J Physiol 1981; 241: G264-9.

15 Morris AI, Turnberg LA. Influence of isoproterenol and propranolol on human intestinal transport in vivo. Gastroenterology 1981; 81: 1076-9.

16 Barclay GR, Turnberg LA. The effect of psychological stress on salt and water transport in the human jejunum. Gastroenterology 1987; 93: 91-7.

17 Sjovall H, Abrahamsson H, Westlander G, et al. Intestinal fluid and electrolyte transport in man during reduced circulating blood volume. .Gut 1986; 27 : 913-8.

18 Barclay GR, Turnberg LA. The influence of sham feeding on salt and water absorption in the human jejunum. Gut 1986; 27: 1147-50.

19 Barclay GR, Turnberg LA. Effect of physical stress on salt and water transport in the human jejunum. Gastroenterology (In press).

20) Cooper H, Levitan R, Fordtran JS, Ingelfinger FJ. A method for studying absorption of water and solutes from the human small intestine. Gastroenterology 1966; 50: $1-7$.

21 Campbell EJM, Dickinson CJ, Slater JDH. Clinical physiology. Oxford: Blackwell Scientific Publications, 1974.

22 Andrew BL, Lenman AR, Lewis DM. Muscular exercise. In: Bell GH, Emslie-Smith D, Paterson CR, eds. Textbook of physiology. Edinburgh: Churchill Livingstone, 1980: 338-43.

23 Schlant RC, Sonnenblick EH. Response to exercise. In: Hurst JW, ed. The heart. New York: McGraw-Hill Book Company, 1986: 55-6.

24 Keele CA, Neil E. Samson Wright's applied physiology. Oxford: Oxford University Press, 1978.

25 Grossman A, Bouloux P, Price P, et al. The role of opioid peptides in the hormonal responses to acute exercise in man. Clin Sci 1984; 67: 483-91.

26 Campbell JHM, Mitchell MB, Powell ATW. The influence of exercise on digestion. Guy's Hosp Rep 1928; 78: 279-93.

27 Hellenbrandt FA, Tepper RH. Studies on the influence of exercise on the digestive work of the stomach II. Its effects on emptying time. Am J Physiol 1934; 107: 355-63.

28 Fordtran JS, Saltin B. Gastric emptying and intestinal absorption during prolonged severe exercise. $J$ Appl Physiol 1967; 23: 331-5.

29 Cammack J, Read NW, Cann PA, Greenwood B, Holgate AM. Effect of prolonged exercise on the passage of a solid meal through the stomach and small intestine. Gut 1982; 23: 957-61.

30 Williams JH, Mager M, Jacobson ED. Relationship of mesenteric blood flow to intestinal absorption of carbohydrate. J Lab Clin Med 1964; 63: 853-63. 
31 Fordtran JS, Rector FC, Carter NW. The mechanisms of sodium absorption in the human small intestine. $J$ Clin Invest 1968; 47: 884-900.

32 Turnberg LA. Intestinal transport of salt and water. Clin Sci Mol Med 1978; 54: 337-48.

33 Isaacs PET, Whitehead JS, Kim YS. Muscarinic acetylcholine receptors of the small intestine and pancreas of the rat: distribution and the effect of vagotomy. Clin Sci 1982; 62: 203-7.

34 Chang EB, Field M, Miller RJ. Enterocyte $\alpha-2$ adrenergic receptors: yohimbine and p-aminoclonidine binding relative to ion transport. Am J Physiol 1983; 244: G76-82.

35 Rowell LB, Blackmon JR, Bruce RA. Indocyanine green clearance and estimated hepatic blood flow during mild exercise to maximal exercise in upright man. J Clin Invest 1964; 43: 1677-90.
36 Varro V, Blaho G, Csernay L, Jung I, Szarvas F. Effect of decreased local circulation on the absorptive capacity of a small intestine loop in the dog. Am J Dig Dis 1965; 10: $170-7$.

37 Brunsson I, Eklund S, Jodal M, Lundgreon O, Sjövall $H$. The effect of vasodilatation and sympathetic nerve action on net water absorption in the cat's small intestine. Acta Physiol Scand 1979; 106: 61-8.

38 Winne D. Der e influss der durchblutung auf die wasserund salzresorption im jejunum der ratte. Naunyn Schmiedebergs Arch Pharmacol 1970; 265: 425-41.

39 Powell DW. Neurohumoral control of intestinal secretion. In: Turnberg LA, ed. Intestinal secretion. Welwyn Garden City: Smith Kline and French Laboratories Limited, 1983: 42-5.

40 Turnberg LA. Control of intestinal secretion. Scand J Gastroenterol 1983; 18: suppl 87: 85-9. 